\title{
Southern Labor Archives
}

\section{Leslie S. Hough}

\author{
Southern Labor Archives
}

The Southern Labor Archives was founded in 1969 out of the coincidence of interest on the part of the trade union and academic communities in the Southeastern United States in creating a repository for materials on the history of the labor movement in the region. Starting in 1971 the Archives gathered such materials, and now makes them available to scholars at its offices in Atlanta. The Archives is a unit of the Library at Georgia State University, and is located in Alumni Hall on the University's downtown campus. Hours for research are 9:00 a.m. to 5:00 p.m., Monday through Friday, and by appointment. Scholars are encouraged to visit and make use of our collections.

In pursuit of its interest in regional labor research resources, the Southern Labor Archives sought the blessing of the state labor federations in the Southeast, beginning with Georgia, and later in other states. State federations in Georgia, Florida. South Carolina, North Carolina, and Virginia gave substantial bodies of records to the Southern Labor Archives. AFL-CIO central bodies in a number of Southern cities, including Atlanta, Birmingham, Augusta, Memphis, and Jacksonville, followed suit.

Two international unions, the United Textile Workers of America and the United Furniture Workers of America have donated their historical records to the Southern Labor Archives. Both represent workers in two of the most important Southern industries, and each of the unions themselves has a most interesting history. Southern regional offices of a number of other international unions, including the Woodworkers, Amalgamated Clothing and Textile Workers, Communication Workers, Ladies Garment Workers, and Machinists have also given records to our repository in Atlanta.

Historical materials from local unions of both industrial and building and construction trades unions are among our most important collections. These records span the period from the late nineteenth century to the $1970 \mathrm{~s}$. International union affiliations of these locals include the Typographers and Machinists among the oldest materials, and Rubber Workers, Asbestos Workers, Carpenters, Electrical Workers, and Printing Pressmen among those donating records of more recent vintage. Workers in the service sector are represented by historical materials from other unions, including Barbers, Firefighters, Paperworkers, Postal Workers, Retail Clerks, Transit Workers, and Nurses. 
Personal papers of leaders of the labor movement in the South are prominent amorg the Southern Labor Archives holdings. Among the individuals involved are Stanton Smith, former President of the Tennessee State Labor Council; John Ramsay, former head of community relations for the CIO Southern Drive: Stetson Kennedy, labor and civil rights activist; Southern CIO official Carey Haigler; and the late Tennessee State Labor Council President, Matt Lynch.

The Southern Labor Archives welcomes inquiries regarding our holdings.

\section{ROOTS OF REBELLION}

Workers' Politics and Organizations in St. Petersburg and Moscow, 1900-1914

\section{by Victoria E. Bonnell}

"Bonnell has combined a sociologist's sense of social structure with an historian's sense of social process in producing an illuminating revision of long-accepted views on Russian workers' politics before the 1917 revolution. She makes a compelling case for the importance of trade unions and the revolutionary movement. . Students of workers' politics and analysts of revolution have as much to learn from Roots of Rebellion as specialists in Russian affairs."-Charles Tilly $\$ 45.00$ hardcover, $\$ 10.95$ paperback

\section{THE RUSSIAN WORKER}

Life and Labor under the Tsarist Regime

\section{Edited by Victoria E. Bonnell}

Written by the workers themselves, and by other observers of working-class life, the selection in this book vividly recreate the world of factory, artisanal, and sales-clerical workers during the final decades of the old regime. These lively and detailed accounts, appearing tor the tirst time in English, are accompanied by Bonnell's informative introduction. $\$ 32.50$ hardcover, $\$ 9.95$ paperback Available at bookstores or order from

\section{UNIVERSITY OF CALIFORNIA PRESS BERKELEY 94720}

